\title{
Phytochemical and pharmacological progress on the genus Syringa
}

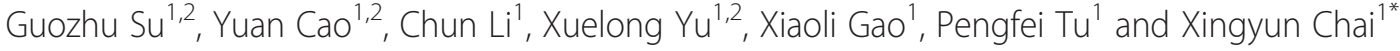

\begin{abstract}
Genus Syringa, belonging to the Oleaceae family, consists of more than 40 plant species worldwide, of which 22 species, including 18 endemic species, are found in China. Most Syringa plants are used in making ornaments and traditional medicines, whereas some are employed for construction or economic use. Previous studies have shown that extracts of Syringa plants mainly contain iridoids, lignans, and phenylethanoids that have antitumor, antihypertensive, anti-oxidant, and anti-inflammatory activities. This study reviews phytochemical and pharmacological progress on Syringa in the recent 20 years and discusses the future research prospects to provide a reference in further promotion and application of the genus.
\end{abstract}

Keywords: Syringa, Oleaceae, Iridoid, Lignan, Phenylethanoid, Bioactivities, Review

\section{Introduction}

Plants belonging to the family Oleaceae, which consists of 27 genera and 400 species worldwide, have important applications in the daily life of people living in developing countries. Plants of many well-known genera, including Forsythia, Syringa, and Osmanthus, have been widely used for medicinal and industrial purposes. For instance, the stems and roots of S. pinnatifolia var. alashanensis is the major composition of atraditional formula 'Ba wei chenxiang' powder that is used for treatment of asthma, cardiopalmus, and angina [1].

Most Syringa plants are deciduous shrubs and arbors and include more than 40 species distributed around Europe and Asia [2]. At present, 22 species are found in China, of which 18 are endemic species that are mainly distributed in the southwestern part of Sichuan, Yunnan, Tibet, and other Northwestern regions. Many Syringa species, such as S. chinensis, S. meyeri, and S. pekinensis, are used for making ornaments. Flowers of S. oblata and S. reticulata var. mandshurica are an ideal source of aroma oils or nectar. Some Syringa plants are also used for construction purposes or for manufacturing furniture [1].

Previous phytochemical studies on Syringa species have revealed the presence of more than 140 secondary

\footnotetext{
* Correspondence: xingyunchai@yeah.net

${ }^{1}$ Modern Research Center for Traditional Chinese Medicine, Beijing University of Chinese Medicine, 11 North 3rd Ring Road, Chaoyang District, Beijing 100029, P. R. China

Full list of author information is available at the end of the article
}

metabolites, including iridoids, lignans, phenylethanoids, their glycosides, minor organic acids, and essential oils $[3,4]$. Modern pharmacological studies have shown the bioactivities of these metabolites, such as antitumor, antihypertensive, anti-oxidant, anti-inflammatory activities, and so on [5]. However, a systematic review of these studies has not been performed to date. This review summarizes the phytochemical and pharmacological progress on Syringa to date by focusing on its chemical classification, structural features, and biological and pharmacological applications to provide information for further research on this genus.

\section{Chemical constituents}

Previous studies have reported that extracts of Syringa plants contain iridoids (1-46), lignans (47-80), phenylpropanoids (81-105), phenylethanoids (106-121), and other compounds (122-142). The structures of these compounds are shown in Figures 1, 2, and 3 and related information are listed in Tables 1, 2, and 3.

\section{Iridoids}

Iridoids are one of the most important natural compounds that are widely distributed in various plant families such as Plantaginaceae, Rubiaceae, and Scrophulariaceae [6]. Iridoids are extensively present in almost all Syringa species and have antitumor, antihypertensive, anti-inflammatory, anti-oxidant, and antifungal activities. In addition, iridoids 


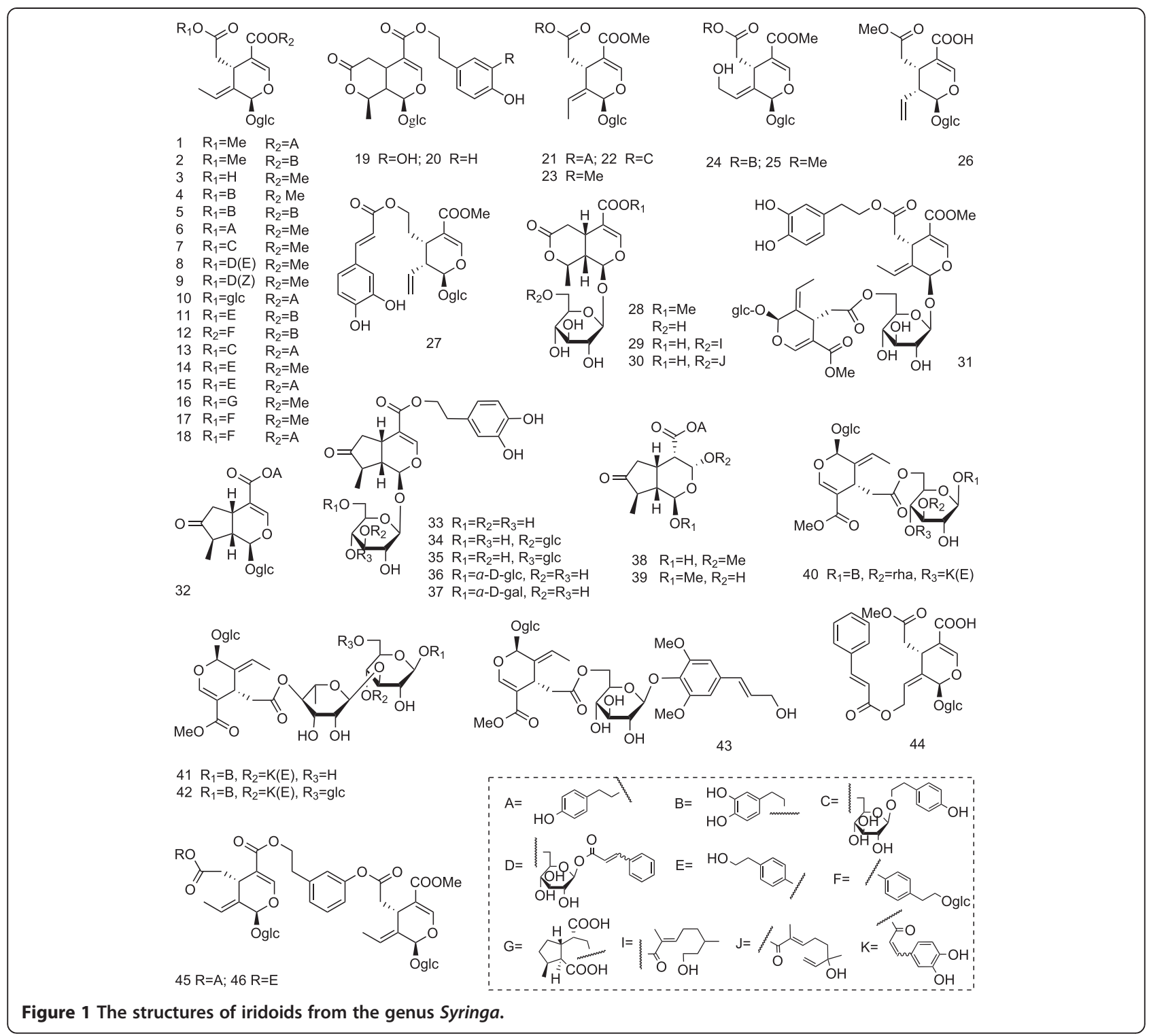

play an important role in defense mechanism of ants [7]. Among all the iridoids reported in this genus, secoiridoids are the most abundant and have been shown to have antitumor activity. To date, 46 iridoids (1-46) have been described, including secoiridoids (1-30 and 40-44), eight typical iridoids (32-39), and three minor dimers (31, 45, and 46). Most iridoids exist as glycosides and are mainly produced by the glycosylation of glucose and galactose. Syringa iridoids are generally substituted by various acid fragments and phenolic moieties such as 1-O-cinnamoyl- $\beta$-D-glucopyranosyl, $p$-hydroxphenethyl, 3, 4-dihydroxy-phenethyl, and caffeic acid, which contribute to their low polarity. Syringa iridoids have antitumor (33 and 40) [8,9], antihypertensive (4), and anti-oxidant (4 and 31) activities [10].

\section{Lignans}

Lignans are another major compounds in this genus, particularly in S. komarowii [27], S. pubescens [3], S. reticulata [10], S. velutina [28], S. patula [5], S. vulgaris [29], S. pinnatifolia var. alashanensis [30,31], and S. reticulata var. mandshurica [32]. Syringa species have 34 lignans and their glycosides (47-80), including monoepoxylignans (47-60, 62) and their dimers (63 and 64), neolignans (61, 73-74), cyclolignans (65 and 66), simple lignans (67-72), and bisepoxylignans (75-80). Lignans also exhibit many bioactivities. For example, compound $\mathbf{5 0}$ has anti-oxidant activity [10]; compounds 57 and 58 have antifungal activities [32]; and compound 75 has significant cytotoxic, antihypertensive, anti-inflammatory, and anti-oxidant activities [5]. 


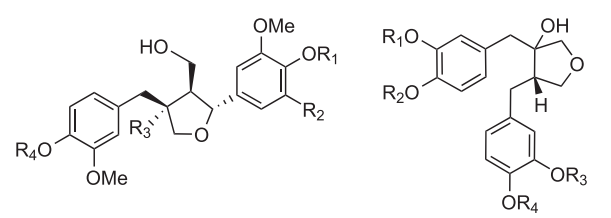

$47 \mathrm{R}_{1}=\mathrm{R}_{2}=\mathrm{R}_{4}=\mathrm{H}, \mathrm{R}_{3}=\mathrm{OH}$ $48 \mathrm{R}_{1}=\mathrm{glc}, \mathrm{R}_{2}=\mathrm{R}_{4}=\mathrm{H}, \mathrm{R}_{3}=\mathrm{OH}$ $49 \mathrm{R}_{1}=\mathrm{R}_{2}=\mathrm{H}, \mathrm{R}_{3}=\mathrm{OH}, \mathrm{R}_{4}=\mathrm{glc}$ $50 R_{1}=R_{3}=H, R_{2}=O M e, R_{4}=g l c$

$$
51 \mathrm{R}_{1}=\mathrm{R}_{3}=\mathrm{Me}, \mathrm{R}_{2}=\mathrm{R}_{4}=\mathrm{H}
$$
$52 \mathrm{R}_{1}+\mathrm{R}_{2}=\mathrm{R}_{3}+\mathrm{R}_{4}=\mathrm{CH}_{2}$<smiles>COc1cc(CC2COC(OC)C2Cc2ccc(O)c(OC)c2)ccc1O</smiles>

$53(a) ; 54(b)$

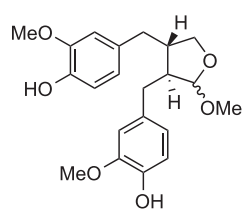

$55(a) ; 56(b)$

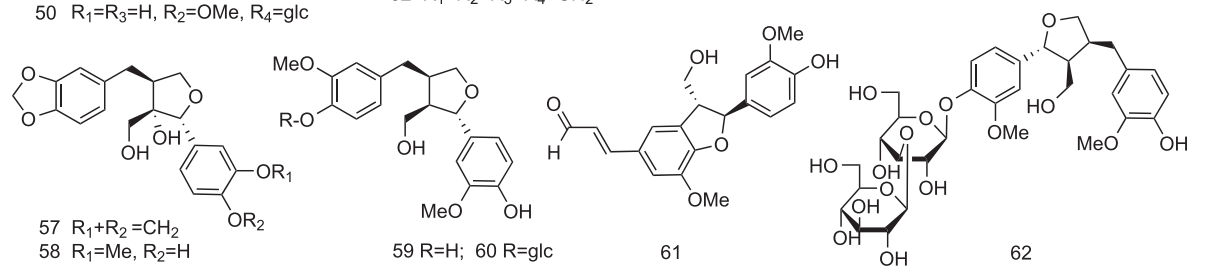

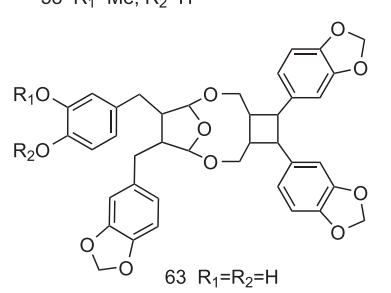<smiles>[2H]Oc1cc2c(cc1OC)[C@H](c1ccc(O)c(OC)c1)[C@H](CO)[C@H](CO)C2</smiles>

61

62<smiles>[R20]Oc1ccc(C[C@@H](CO)[C@H](CO)Cc2ccc([R20])c([R6])c2)cc1[R20]</smiles>

$67 \mathrm{R}_{1}=\mathrm{R}_{3}=\mathrm{Me}, \mathrm{R}_{2}=\mathrm{R}_{4}=\mathrm{H}$ $68 \mathrm{R}_{1}+\mathrm{R}_{2}=\mathrm{CH}_{2}, \mathrm{R}_{3}=\mathrm{Me}, \mathrm{R}_{4}=\mathrm{H}$ $69 \mathrm{R}_{1}+\mathrm{R}_{2}=\mathrm{R}_{3}+\mathrm{R}_{4}=\mathrm{CH}_{2}$

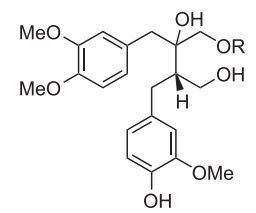

65 (b) R=glc; 66 (a) R=H
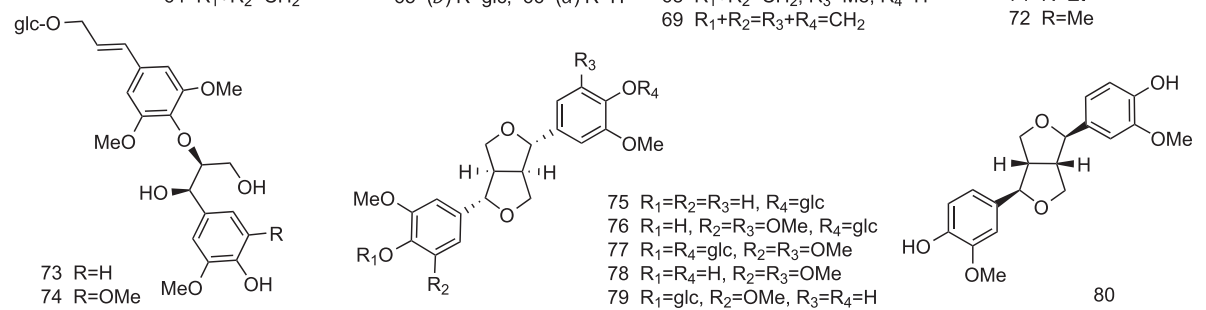

Figure 2 The structures of lignans from the genus Syringa.

\section{Other compounds}

Phenylethanoids (81-105), phenylpropanoids and their analogues (106-121), flavonoids (122-128), sesquiterpenes (129 and 130), and other minor compounds have been described in Syringa plants. Of these, phenylethanoids are predominant, particularly in $S$. reticulata [10,12,35], S. vulgaris [29], S. pubescens [3], S. oblata var. alba [36], S. reticulata var. mandshurica [35], S. afghanica [13], and S. komarowii [27]. Sesquiterpenes (129 and 130) are present in the stems of S. pinnatifolia var. alashanensis [37]. These miscellaneous compounds have cytotoxic, anti-inflammatory, antihypertensive, anti-oxidant, and antifungal properties.

Besides the abovementioned compounds, Syringa plants contain essential oils that form the most important constituents not only because of their economic utility but also because of their potential medicinal value as antimicrobial, antipyretic, and antiviral agents. Multiple analytical techniques such as headspace solid-phase microextraction, gas chromatography-mass spectrometry (GC-MS), GC-MS coupled with heuristic evolving latent projections, moving subwindow searching, nuclear magnetic resonance spectroscopy, and X-ray single-crystal diffraction analysis have been used to identify essential oils from fresh flowers of S. oblata var. alba. For instance, 39 volatile oil constituents were identified, including four characteristic isomers of lilac alcohols (lilac alcohols A-D) and lilac aldehydes A-D [38]. Ninety-five components, including 15 terpenes, 14 oxygenated terpenes, 10 aromatic compounds, and $13 n$-alkanes were quantitatively analyzed from S. oblata buds [39]. Forty-nine components were described from essential oil of $S$. pubescens flowers, most of which are monoterpenes and sesquiterpenes [40]. Thirtyfour volatile oil components, accounting for around $64.7 \%$ (zerumbone) of the toil oil, were identified from roots and barks of S. pinnatifolia var. alashanensis [4]. These data imply that Syringa plants could be considerably different from each other in terms of their essential oil components.

\section{Pharmacological activities}

Various crude extracts and isolated compounds from Syringa plants have shown significant antitumor, antihypertensive, anti-inflammatory, anti-oxidant, and antifungal activities. 


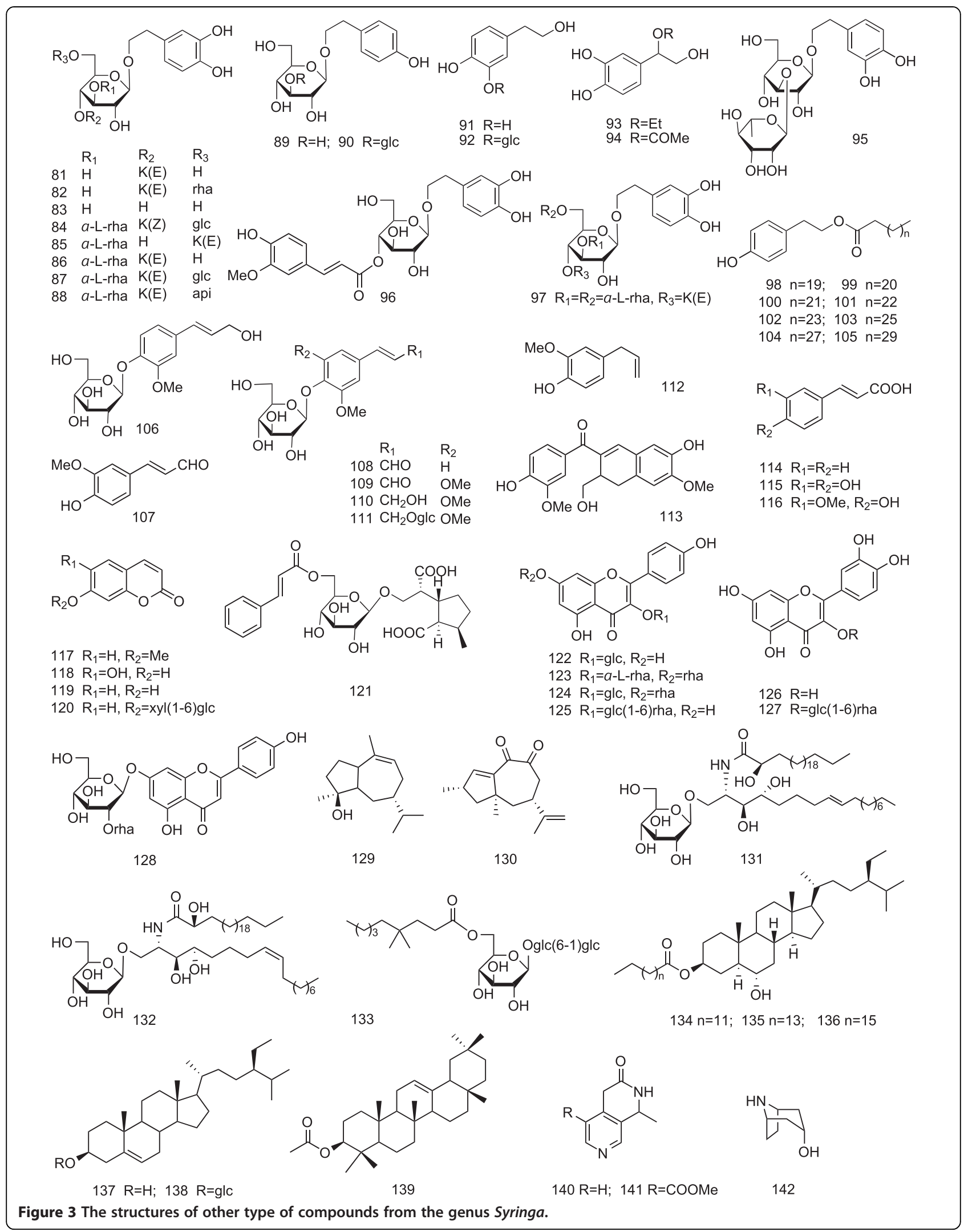


Table 1 Iridoids from the genus Syringa

\begin{tabular}{|c|c|c|c|c|}
\hline No & Compound & Part of plants & Source & Reference \\
\hline 1 & Isoligustroside & leaves & S. vulgaris & [11] \\
\hline 2 & Isooleuropein & leaves & S. vulgaris & {$[11]$} \\
\hline \multirow[t]{2}{*}{3} & Oleoside 11-methyl ester & flowers, leaves and floral buds & S. pubescens & {$[3,5]$} \\
\hline & & & S. patula & \\
\hline \multirow[t]{2}{*}{4} & Oleuropein & flowers, leaves, barks and floral buds & S. pubescens & {$[3,5,8,10,12-14]$} \\
\hline & & & $\begin{array}{l}\text { S. reticulata, S. dilatata, } \\
\text { S. velutina, S. afghanica, } \\
\text { S. oblata var. alba, S. patula }\end{array}$ & \\
\hline 5 & Neooleuropein & leaves & S. vulgaris & {$[15]$} \\
\hline 6 & 8(E)-Ligstroside & flowers, leaves and barks & $\begin{array}{l}\text { S. pubescens, S. reticulata, } \\
\text { S. dilatata, S. afghanica }\end{array}$ & {$[3,8,10,13]$} \\
\hline 7 & 8(E)-Nüzhenide & leaves & S. reticulata & {$[16]$} \\
\hline 8 & Safghanoside A & leaves & S. afghanica & {$[13]$} \\
\hline 9 & Safghanoside B & leaves & S. afghanica & [13] \\
\hline 10 & Safghanoside C & leaves & S. afghanica & [13] \\
\hline 11 & Safghanoside D & leaves & S. afghanica & [13] \\
\hline 12 & Safghanoside E & leaves & S. afghanica & [13] \\
\hline 13 & Safghanoside F & leaves & S. afghanica & {$[13]$} \\
\hline 14 & Formoside & leaves & S. afghanica & {$[13]$} \\
\hline 15 & Fraxiformoside & leaves & S. afghanica & [13] \\
\hline 16 & 2"-epi-frameroside & leaves & S. afghanica & [13] \\
\hline 17 & 1"'-O- $\beta$-D-glucosylformoside & leaves & S. afghanica & {$[13]$} \\
\hline 18 & 1"'-O- $\beta$-D-glucosylfraxiformoside & leaves & S. afghanica & [13] \\
\hline 19 & Lilacoside & barks and leaves & S. vulgaris & {$[17,18]$} \\
\hline 20 & Fliederoside & barks and leaves & S. vulgaris & {$[17,18]$} \\
\hline 21 & 8(Z)-Ligstroside & leaves & S. reticulata & [16] \\
\hline 22 & 8(Z)-Nüzhenide & leaves & S. reticulata & {$[16]$} \\
\hline 23 & Oleoside dimethyl ester & leaves & S. afghanica & {$[13]$} \\
\hline 24 & 10-Hydroxyoleuropein & flowers and leaves & S. pubescens & [3] \\
\hline 25 & 10-Hydroxyoleoside dimehyl ester & flowers and leaves & S. pubescens & [3] \\
\hline 26 & Secologanoside 7-methyl ester & leaves & S. reticulata & [19] \\
\hline 27 & Grandifloroside 11-methyl ester & flowers and leaves & S. pubescens & [3] \\
\hline 28 & 8-Epikingiside & barks & S. vulgaris & {$[20]$} \\
\hline 29 & Syrveoside A & leaves & S. velutina & {$[21]$} \\
\hline 30 & Syrveoside B & leaves & S. velutina & {$[21]$} \\
\hline 31 & Jaspolyoside & barks & S. reticulata & {$[10]$} \\
\hline 32 & Syringopicroside & leaves & $\begin{array}{l}\text { S. dilatata, S. vulgaris, } \\
\text { S. oblata, S. reticulata }\end{array}$ & {$[8,16,19,22,23]$} \\
\hline 33 & Syringopicroside B & leaves & S. vulgaris & [9] \\
\hline 34 & 3'-O- $\beta$-D-glucopyranosylsyring-opicroside & leaves & S. reticulata & {$[16]$} \\
\hline 35 & 4'-O- $\beta$-D-glucopyranosylsyring-opicroside & leaves & S.reticulata & {$[16]$} \\
\hline 36 & 6'-O-a-D-glucopyranosylsyring-opicroside & leaves & S. reticulata & {$[16]$} \\
\hline 37 & 6'-O- $\alpha$-D-galactopyranosylsyring-opicroside & leaves & S. reticulata & {$[19]$} \\
\hline 38 & Syringopicrogenin $C$ & seeds & S. oblata & [24] \\
\hline 39 & Syringopicrogenin A & seeds and crust & S. oblata & {$[24,25]$} \\
\hline
\end{tabular}


Table 1 Iridoids from the genus Syringa (Continued)

\begin{tabular}{llll}
\hline $\mathbf{4 0}$ & Isooleoacteoside & leaves & S. vulgaris \\
$\mathbf{4 1}$ & Oleoacteoside & leaves & S. reticulata \\
$\mathbf{4 2}$ & Oleoechinacoside & leaves & S. reticulata \\
$\mathbf{4 3}$ & Reticuloside & barks & {$[9,26]$} \\
$\mathbf{4 4}$ & Jasminoside & whole plant & S. reticulata \\
$\mathbf{4 5}$ & Safghanoside H & leaves & S. komarowii \\
$\mathbf{4 6}$ & Safghanoside G & leaves & S. afghanica \\
\hline
\end{tabular}

\section{Antitumor activity}

Cytotoxic activities of crude extracts and chemicals obtained from Syringa plants have been extensively evaluated against various tumor cell lines. Aqueous extracts from the flowers and leaves of $S$. pubescens inhibited the growth of L2215 (hepatitis B virus) cells, with a 50\% inhibitory concentration $\left(\mathrm{IC}_{50}\right)$ value of $78 \mu \mathrm{g} / \mathrm{mL}$ [51]. Hydrolysis of isoligustroside (1) and isooleuropein (2) were assayed using a disease-oriented panel of 39 human cancer cell lines. The results showed that the hydrolysis product of compound $\mathbf{2}$ had moderate cytotoxic activity against lung cancer cell lines DMS273 $\left[\log \mathrm{GI}_{50}=5.19\right.$ $(6.4 \mu \mathrm{M})]$ and DMS114 $\left[\log \mathrm{GI}_{50}=5.06(8.7 \mu \mathrm{M})\right]$. Preliminary analysis of structure-activity relationship suggested that $\mathrm{C}-5^{\prime}-\mathrm{OH}$ plays an important role in this cytotoxic activity [11]. Isooleoacteoside (40) showed weak cytotoxicity against LOX-IMVI melanoma cell line, with $\mathrm{GI}_{50}$ value of $16 \mu \mathrm{M}$, and syringopicroside $\mathrm{B}$ (33) showed weak cytotoxic activity against NCI-H522 lung cancer cell line, with $\mathrm{GI}_{50}$ value of $13 \mu \mathrm{M}$ [9]. MTT assay used to assess the cytotoxicities of syringaresinol (78) and oleoside 11-methyl ester (3) showed that compound 78 had a strong dose-dependent effect on HepG2 cell line, with an $\mathrm{IC}_{50}$ value of $94.6 \mu \mathrm{M}$, and compound 3 has a dose-response curve of low slope, with a high $\mathrm{IC}_{50}$ value of $186.5 \mu \mathrm{M}$, compared with positive controls dexamethasone $\left(\mathrm{IC}_{50} 14.2 \mu \mathrm{M}\right)$ and paclitaxel $\left(\mathrm{IC}_{50} 700\right.$ $\mathrm{nM})$. However, compound $\mathbf{7 8}$ was cytotoxic even at the lowest concentration of $29.9 \mu \mathrm{M}$. $\beta$-Amyrin acetate (139) showed weak cytotoxicity against A2780 human ovarian cancer and HepG2 cell lines [5]. Oleuropein (4) and 2-(3, 4-dihydroxy)-phenylethyl- $\beta$-D-glucopyranoside (83) showed evident cytotoxicities against P-388, L-1210, SNU-5, and HL-60 cell lines, with $\mathrm{IC}_{50}$ values varying from 8.5 to $139.8 \mu \mathrm{M}$ [12]. Verbascoside (86) showed moderate cytotoxic activity against SNB-75 (brain cancer) and SNB-78 cell lines, with $\mathrm{GI}_{50}$ values of 7.4 and $7.7 \mu \mathrm{M}$, respectively [9]. A pharmacokinetic study showed that compound 86 interacted with the catalytic domain of PKC and acted as a competitive inhibitor of adenosine triphosphate $\left(K_{\mathrm{i}}=22 \mu \mathrm{M}\right)$ and non-competitive inhibitor of phosphate acceptor (histone III). Because 83 is one part of
86 in its molecular structure, the cytotoxic effect could be attributed to 3, 4-dihydroxyphenylethoxy moiety, which may act as a competitive inhibitor to the catalytic domain of PKC. Therefore, $\mathbf{8 3}$ is a potentially essential skeleton of most cytotoxic phenylethanoid glycosides [12].

\section{Hypotensive activity}

Syringin (110) and kaempferol-3-O-rutinoside (125) showed antihypertensive activity. Intravenous injection of $10 \mathrm{mg} / \mathrm{kg}$ of compound $\mathbf{8 6}$ significantly decreased systolic, diastolic, and mean arterial blood pressure in Pentothal-anesthetized rats. Moreover, the depressor effect of compound 86 was independent of muscarinic and histaminergic receptors because it did not block the effect of atropine (an antimuscarinic agent) and chlorpheniramine/cimetidine (antihistaminergic agents) [36]. In vitro studies showed that oleuropein (4) significantly lowered blood pressure. It is interesting to note that antihypertensive effect of compound $\mathbf{4}(33 \%$ at $30 \mathrm{mg} / \mathrm{kg}$ dose) on the blood pressure of anesthetized rats was similar to that of compound $\mathbf{8 6}(39.04 \% \pm 2.38 \%$ at 10 $\mathrm{mg} / \mathrm{kg}$ dose) $[14,36]$, which is probably because of the similarity in their structures, with both possessing the same aromatic fragment having two hydroxy groups.

\section{Anti-inflammatory activity}

Iridoid glycosides (IGs) exerted obvious anti-inflammatory effects on ulcerative colitis in vivo by inhibiting relative proinflammatory cytokines [53]. IGs significantly ameliorated macroscopic damages and histological changes, reduced the activity of myeloperoxidase, and strongly inhibited epithelial cell apoptosis. Moreover, IGs markedly decreased the levels of tumor necrosis factor- $\alpha$, interleukin8 , cyclooxygenase- 2 , and transforming growth factor- $\beta 1$ in colonic tissues in a dose-dependent manner. Moreover, effects of IGs (160 and $240 \mathrm{mg} / \mathrm{kg}$ ) were superior to those of positive control salicylazosulfapyridine $(150 \mathrm{mg} / \mathrm{kg})$. Furthermore, IGs significantly blocked NF-kB signaling by inhibiting inflammatory bowel phosphorylation/degradation and inhibitor kappa $\mathrm{B}$ kinase $\beta$ activity; downregulated protein and mRNA expressions of Fas/FasL, Bax, and caspase-3; and activated Bcl-2 in intestinal epithelial cells 
Table 2 Lignans from the genus Syringa

\begin{tabular}{|c|c|c|c|c|}
\hline No & Name & Part of plant & Source & Reference \\
\hline 47 & (-)-Olivil & whole plant & S. komarowii & [27] \\
\hline 48 & Olivil 4-O- $\beta$-D-glucopyranoside & barks & S. reticulata, S. patula & [10] \\
\hline 49 & Olivil 4"-O- $\beta$-D-glucopyranoside & barks & S. reticulata & [27] \\
\hline 50 & Armandiside & barks & S. reticulata & [10] \\
\hline 51 & Syripinnalignan A & roots and stems & S. pinnatifolia var. alashanensis & [31] \\
\hline 52 & Syripinnalignan B & roots and stems & S. pinnatifolia var. alashanensis & [31] \\
\hline 53 & $\left(8 R, 8^{\prime} R, 9 S\right)-4-4^{\prime}$-dihydroxy-3, 3', 9-trimethoxy-9-9'-epoxylignan & roots and stems & S. pinnatifolia var. alashanensis & [30] \\
\hline 54 & $\left(8 R, 8^{\prime} R, 9 R\right)-4-4^{\prime}$-dihydroxy-3, 3', 9-trimethoxy-9-9'-epoxylignan & roots and stems & S. pinnatifolia var. alashanensis & [30] \\
\hline 55 & $\left(8 S, 8^{\prime} S, 9 R\right)-4-4^{\prime}$-dihydroxy-3, 3', 9-trimethoxy-9-9'-epoxylignan & roots and stems & S. pinnatifolia var. alashanensis & [30] \\
\hline 56 & $\left(85,8^{\prime} S, 95\right)-4-4^{\prime}$-dihydroxy-3, 3', 9-trimethoxy-9-9'-epoxylignan & roots and stems & S. pinnatifolia var. alashanensis & [30] \\
\hline 57 & Mandshuricol A & leaves & S. reticulata var. mandshurica & {$[32]$} \\
\hline 58 & Mandshuricol B & leaves & S. reticulata var. mandshurica & [32] \\
\hline 59 & $(+)$-Lariciresinol & seeds crust & S. oblata & [25] \\
\hline 60 & (+)-Lariciresinol 4-O- $\beta$-D-glucopyranoside & barks & S. vulgaris & [29] \\
\hline 61 & Balanophonin & roots and stems & S. pinnatifolia var. alashanensis & {$[30]$} \\
\hline 62 & $\begin{array}{l}\text { (+)-Lariciresinol 4'-O- } \beta \text {-D-glucopyran } \\
\text {-osyl-( }(\rightarrow 3)-\beta \text {-D-glucopyranoside }\end{array}$ & leaves & S. reticulata & [19] \\
\hline 63 & Syripinnalignin A & roots and stems & S. pinnatifolia var. alashanensis & {$[33]$} \\
\hline 64 & Syripinnalignin B & roots and stems & S. pinnatifolia var. alashanensis & {$[33]$} \\
\hline 65 & Cycloolivil 6-O- $\beta$-D-glucoside & barks & S. reticulata & {$[10]$} \\
\hline 66 & (+)-Cycloolivil & whole plant & S. komarowii & {$[27]$} \\
\hline 67 & (-)-Secoisolariciresinol & stems & S. pinnatifolia var. alashanensis & {$[30,31]$} \\
\hline 68 & PiperphilippininVl & roots and stems & S. pinnatifolia & {$[30]$} \\
\hline 69 & Dihydrocubebin & roots and stems & S. pinnatifolia var. alashanensis & {$[30]$} \\
\hline 70 & Syripinnalignan C & roots and stems & S. pinnatifolia var. alashanensis & [34] \\
\hline 71 & Syripinnalignan D & roots and stems & S. pinnatifolia var. alashanensis & [34] \\
\hline 72 & Syripinnalignan E & roots and stems & S. pinnatifolia var. alashanensis & {$[34]$} \\
\hline 73 & $\begin{array}{l}\text { (7S, 8R)-Guaiacylglycerol-8-O-4'-sinapyl } \\
\text { ether 9'-O- } \beta \text {-D-glucopyranoside }\end{array}$ & leaves & S. velutina & {$[28]$} \\
\hline 74 & $\begin{array}{l}\text { (7S, 8R)-Syringylglycerol-8-O-4'-sinapyl } \\
\text { ether 9'-O- } \beta \text {-D-glucopyranoside }\end{array}$ & leaves & S. velutina & {$[28]$} \\
\hline 75 & Pinoresinol-4-O- $\beta$-monoglycoside & barks & S. reticulata & [10] \\
\hline 76 & Syringaresinol-4-O-bis- $\beta$-D-monoglucoside & barks & S. reticulata & [10] \\
\hline 77 & Syringaresinol-4, 4"-O-bis- $\beta$-D-glucoside & barks & S. reticulata & {$[10]$} \\
\hline 78 & Syringaresinol & floral buds, flowers and leaves & S. patula, S. pubescens & {$[3,5]$} \\
\hline 79 & (+)-Medioresinol-4-O-glucoside & floral buds & S. patula & {$[5]$} \\
\hline 80 & (-)-Pinoresinol & roots and stems & S. pinnatifolia var. alashanensis & {$[30]$} \\
\hline
\end{tabular}

$[53,54] . \beta$-Amyrin acetate (139) and syringaresinol (78) at a dose of $20 \mu \mathrm{g} / \mathrm{mL}$ evidently inhibited lipopolysaccharideinduced nitric oxide $(\mathrm{NO})$ production, with inhibition rates of $49.97 \%$ and $33.21 \%$, respectively [5].

\section{Liver-protective and cholagogic effects}

Crude extract of Syringa species, interferon (IFN), and an injection of "Gan-Yan-Ling" were compared to evaluate their liver-protective effects on the survival rates of HepG2.215 cells and secretion of hepatitis $B$ surface antigen (HBsAg) and HBeAg. The results indicated that all the three assayed drugs may suppress the secretion of HBsAg and HBeAg from HepG2.215 cells in a dose-dependent manner, with the effect of crude extract of Syringa being intermediate those of IFN and Gan-Yan-Ling. Therefore, extracts of Syringa plant 
Table 3 Other type of compounds from the genus Syringa

\begin{tabular}{|c|c|c|c|c|}
\hline No & Name & Part of plant & Source & Reference \\
\hline 81 & Isosyringalide & leaves & S. reticulata & [41] \\
\hline 82 & Forsythiaside & barks & S. vulgaris & [29] \\
\hline 83 & 2-(3, 4-dihydroxy)-phenylethyl- $\beta$-D-glucopyranoside & barks & S. reticulata & {$[10,12]$} \\
\hline 84 & cis-Echinacoside & leaves & S. reticulata & {$[35]$} \\
\hline 85 & Isoverbascoside & leaves & S. pubescens & [3] \\
\hline 86 & Verbascoside & leaves & S. pubescens, S. oblata var. alba, S. vulgaris & {$[3,9,29,14,36]$} \\
\hline \multirow[t]{2}{*}{87} & Echinacoside & barks, leaves and flowers & S. pubescens, S. reticulata & {$[3,29,42]$} \\
\hline & & & S. vulgaris & \\
\hline 88 & Forsythoside B & leaves & S. reticulata var. mandshurica & [35] \\
\hline 89 & Salidroside & barks & S. reticulata & [10] \\
\hline 90 & 3'-O- $\beta$-D-glucopyranosysalidroside & leaves & S. reticulata var. mandshurica & {$[35]$} \\
\hline 91 & 2-(3, 4-dihydroxyphenyl) ethanol & leaves & S. pubescens & [3] \\
\hline 92 & Osmanthuside F & leaves & S. reticulata & {$[35]$} \\
\hline 93 & (S)-(+)-2-(3, 4-dihydroxyphenyl)-2-ethoxylethanol & leaves & S. reticulata var. mandshurica & {$[43]$} \\
\hline 94 & (S)-(+)-2-(3, 4-dihydroxyphenyl)-2-acetoxyethanol & leaves & S. reticulata var. mandshurica & [43] \\
\hline 95 & Decaffeoylacteoside & leaves & S. reticulata & [35] \\
\hline 96 & Syringalide B & leaves & S. reticulata & [41] \\
\hline 97 & Poliumoside & leaves & S. afghanica & [13] \\
\hline 98 & 2-(4-hydroxypenyl)-ethyl behenate & whole plant & S. komarowii & [27] \\
\hline 99 & 2-(4-hydroxypenyl)-ethyl tricosanoate & whole plant & S. komarowii & [27] \\
\hline 100 & 2-(4-hydroxypenyl)-ethyl lignocerate & whole plant & S. komarowii & [27] \\
\hline 101 & 2-(4-hydroxyhenyl)-ethyl pentacosanoate & whole plant & S. komarowii & [27] \\
\hline 102 & 2-(4-hydroxypenyl)-ethyl hexacosanoate & whole plant & S. komarowii & [27] \\
\hline 103 & Bongardol & whole plant & S. komarowii & [27] \\
\hline 104 & 2-(4-hydroxypenyl)-ethyl 1-dodecyloctadecanoate & whole plant & S. komarowii & [27] \\
\hline 105 & 2-(4-hydroxypenyl)-ethyl dotriacontanoate & whole plant & S. komarowii & [27] \\
\hline 106 & Coniferin & barks & S. vulgaris & [29] \\
\hline 107 & Coniferylaldehydel & roots and stems & S. pinnatifolia var. alashanensis & [44] \\
\hline 108 & Coniferyaldehyde glucoside & barks & S. reticulata & [10] \\
\hline 109 & Sinapaldehyde glucoside & barks & S. reticulata & [10] \\
\hline 110 & Syringin & barks & S. vulgaris, S. reticulata & {$[10,45,46]$} \\
\hline 111 & Isosyringinoside & barks & S. reticulata & {$[10]$} \\
\hline 112 & Eugenol & foral buds & S. patula & {$[5]$} \\
\hline 113 & Larixnaphthanoe & roots and stems & S. pinnatifolia var. alashanensis & {$[30]$} \\
\hline 114 & Cinnamic acid & leaves, roots and stems & $\begin{array}{l}\text { S. afghanica, S. pinnatifolia } \\
\text { var. alashanensi, S. reticulata }\end{array}$ & {$[44,47]$} \\
\hline 115 & Caffeic acid & roots and stems & S. pinnatifolia var. alashanensis & {$[44]$} \\
\hline 116 & Ferulic acid & roots and stems & S. pinnatifolia var. alashanensis & [44] \\
\hline 117 & 7-Methoxycoumarin & roots and stems & S. pinnatifolia var. alashanensis & [44] \\
\hline 118 & Esculetine & roots and stems & S. pinnatifolia var. alashanensis & [44] \\
\hline 119 & Umbelliferone & roots and stems & S. pinnatifolia var. alashanensis & [44] \\
\hline 120 & $\begin{array}{l}\text { O-[ } \beta \text {-D-xylopyanosy }(1-6) \\
\beta \text {-D-glucopyranosyl]-7-hydroxycoumarin }\end{array}$ & roots and stems & S. pinnatifolia var. alashanensis & {$[44]$} \\
\hline 121 & Syringfghanoside & leaves & S. afghanica & [13] \\
\hline 122 & Astragalin & bark & S. vulgaris & [48] \\
\hline
\end{tabular}


Table 3 Other type of compounds from the genus Syringa (Continued)

\begin{tabular}{|c|c|c|c|c|}
\hline 123 & Kaempferol-3, 7-a-L-dirhamnoside & flowers and leaves & S. pubescens & [3] \\
\hline 124 & Kaempferol-3- $\beta$-D-glucoside-7- $\alpha$-L-dirhamnoside & flowers and leaves & S. pubescens & [3] \\
\hline 125 & Kaempferol-3-O-rutinoside & flowers & S. vulgaris & [49] \\
\hline 126 & Luteolin & leaves & S. afghanica & [13] \\
\hline 127 & Rutin & leaves & S. vulgaris & {$[49,50]$} \\
\hline 128 & Rhoifolin & leaves & S. afghanica & [13] \\
\hline 129 & 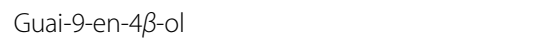 & roots and stems & S. pinnatifolia var. alashanensis & [37] \\
\hline 130 & 14, 15-dinorguai-1, 11-dien-9, 10-dione & roots and stems & S. pinnatifolia var. alashanensis & [37] \\
\hline 131 & Momorcerebroside I & whole plant & S. komarowii & [27] \\
\hline 132 & Phytolacca cerebroside & whole plant & S. komarowii & [27] \\
\hline 133 & Pubescenside A & flowers and leaves & S. pubescens & [51] \\
\hline 134 & Stigmastane-3 $\beta, 6 a$-diol 3-O-tetradecanoate & whole plant & S. komarowii & [27] \\
\hline 135 & Stigmastane-3 $\beta$, 6a-diol 3-0-palmitate & whole plant & S. komarowii & {$[27]$} \\
\hline 136 & Stigmastane-3 $\beta$, 6a-diol 3-O-stearate & whole plant & S. komarowii & [27] \\
\hline 137 & $\beta$-sitosterol & foral buds and whole plant & S. patula, S. komarowii & {$[5,27]$} \\
\hline 138 & Daucosterol & whole plant & S. komarowii & {$[27]$} \\
\hline 139 & $\beta$-Amyrin acetate & foral buds & S. patula & [5] \\
\hline 140 & Jasminidin & leaves & S. vulgaris & [52] \\
\hline 141 & Jasminin & leaves & S. vulgaris & [52] \\
\hline 142 & Nortropin & foral buds & S. patula & [5] \\
\hline
\end{tabular}

could be used to develop effective and less toxic antihepatitis B medicines [55].

Aqueous extracts of $S$. reticulata var. mandshurica significantly decreased the levels of alanine transaminase and aspartate transaminase and the concentration of malondialdehyde in the serum but increased the activity of superoxide dismutase (SOD) in the liver. These extracts showed protective effects on acute liver injury induced by $\mathrm{CCl}_{4}$ in mice [56]. In addition, the essential oils of Syringa exerted protective effects on the liver and cholecyst [39].

\section{Antifungal activity}

Phenylpropanoids such as verbascoside (86) and forsythiaside (82) exhibit significant antimicrobial activity [29]. Compounds 93 and 94 at 1- mM concentration inhibited the radial growth of Phytophthora capsici after 6 days of incubation, with inhibition rates 59.1\% and $72.5 \%$, respectively [43]. Two sesquiterpenes, guai-9-en$4 \beta$-ol (129) and 4, 15-dinorguai-1, 11-dien-9, 10-dione (130), have antibacterial and antifungal properties. Compound 129 was active against Bacillus coagulans [inhibition zone $(\mathrm{IZ})=15.34 \mathrm{~mm}$ ] and Aspergillus niger (IZ = $13.20 \mathrm{~mm}$ ) while compound $\mathbf{1 3 0}$ significantly inhibited Escherichia coli $(\mathrm{IZ}=15.34 \mathrm{~mm})$ and Fusarium oxysporum (IZ = $15.32 \mathrm{~mm})$ [37].

Compound 3 showed effective antimicrobial activity against Lactobacillus pentosus (IZ = $1 \mathrm{~mm})$, and compound
139 inhibited the growth of Candida species at concentrations of $30-250 \mu \mathrm{g} / \mathrm{mL}$ [5].

\section{Antioxidant activity}

A 70\% EtOH extract of $S$. reticulata barks showed potent superoxide anion and DPPH free radical scavenging activities, with $\mathrm{EC}_{50}$ values of 5.88 and $38.10 \mu \mathrm{g} / \mathrm{mL}$, respectively [10].

Among the compounds isolated from the bark of $S$. reticulata, six (4, 31, 50, 77, 83, and 111) showed significant superoxide anion scavenging activity, with $\mathrm{EC}_{50}$ values of $2.57,4.97,10.64,15.98,4.97$, and $14.14 \mu \mathrm{g} / \mathrm{mL}$, respectively. Compound $\mathbf{4}$ also interacted with the stable free radical $\mathrm{DPPH}$, with an $\mathrm{IC}_{50}$ value of $40.4 \mu \mathrm{M}[8,10]$. These different anti-oxidant activities are closely related to their structural features. Presence of 2-(3, 4-dihydroxyphenyl)-ethoxy moiety might be important for a higher activity because the most potent compounds $\left(\mathrm{EC}_{50}=2.57-4.97 \mu \mathrm{M}\right)$, including the two secoiridoid glycosides (31 and 4) and a phenylethanoid glycoside (83), possess the same structural features. Comparison of the structures of compounds 4 and 83 with those of $8(Z)$-ligstroside (21) and salidroside (89) showed that presence of ortho-coupling hydroxyl group at C-2 might be responsible for their different activities. It has been previously reported that 1, 2-dihydroxybenzene moiety is crucial to its DPPH scavenging activity [10]. 
Syringaresinol (78) showed a strong scavenging activity against $\mathrm{DPPH}$, with $\mathrm{EC}_{50}$ value as low as $12.5 \mu \mathrm{g} / \mathrm{mL}$, which might be responsible for its strong inhibition of NO production [5].

Eugenol (112) inhibited the catalytic activity of $\mathrm{H}_{2} \mathrm{O}_{2}$ / $\mathrm{Ca}^{2+}$ human erythrocyte membrane lipid peroxidation at a concentration of $200 \mu \mathrm{mol} / \mathrm{L}$, with an inhibition rate of $62 \%$, and completely suppressed the catalytic activity of dibenzoyl peroxide/ $\mathrm{Ca}^{2+}$ human erythrocyte membrane lipid peroxidation at a concentration of $100 \mu \mathrm{mol} / \mathrm{L}$. Compound 112 exerted its effect in a non-competitive manner by reacting with $\mathrm{Ca}^{2+}$ and inhibiting the formation of hydroxyl radicals, thus, protecting the cell membrane lipid from oxidation [2].

\section{Inhibition of platelet aggregation}

Aqueous extract of S. aramaticum significantly inhibited adenosine diphosphate (ADP) and collagen-induced platelet aggregation, with inhibition rates of $37.4 \%$ and $69.7 \%$, respectively [57]. Mandshuricols A (57) and B (58) showed antagonistic activities on platelet-activating factor (PAF) in [3H]PAF receptor binding assay, with $\mathrm{IC}_{50}$ values of $4.8 \times 10^{-5}$ and $3.5 \times 10^{-5} \mathrm{M}$, respectively [32].

\section{Others}

Essential oils from the stems and roots of S. pinnatifolia var. alashanensis (SPEO) reduced the deviation of ST segment; decreased the levels of lactate dehydrogenase, creatine kinase, and troponin T; and increased the activity of SOD. These protective effects were further confirmed by histopathological examination [58]. Treatment with both 8 and $32 \mathrm{mg} / \mathrm{kg}$ SPEO prolonged the survival of mice under hypoxia conditions, showing a remarkable protective effect against $\mathrm{H}_{2} \mathrm{O}_{2}$-induced death in cultured rat myocytes. Moreover, 5, 2.5 and $1.25 \mu \mathrm{g} / \mathrm{mL}$ doses of SPEO inhibited ADP-induced rat platelet aggregation by $47.4 \%$, $37.0 \%$, and $32.9 \%$, respectively [58], implying that SPEO exerted protective effects against myocardial ischemia.

Oral and intraperitoneal administration of $0.2-0.4 \mathrm{~g}$ of leaf extract of $S$. vulgaris in cats or rabbits exerted an antipyretic effect that was equal to the effect of $0.1-0.3$ $\mathrm{g}$ of aminopyrine administered orally or intraperitoneally. However, leaf extracts of S. vulgaris are considerably more toxic than aminopyrine, with their toxic dosages being 0.4 and $1.2 \mathrm{~g} / \mathrm{kg}$, respectively [59]. In vitro evaluation of leaf extract of $S$. aramaticum showed its antiviral activity against herpes simplex virus at concentrations $1.25 \%-2.5 \%$. The protective effect was more obvious when controlling the amount of virus attacks at 9.2-92 tissue culture infective dose (TCID50), suggesting that $S$. aramaticum effectively killed the virus without any harmful side effects [60-62].

Studies have reported that leaf extracts of $S$. aramaticum could be used for treating hemorrhoids [63].
Eugenol (112) inhibited the metabolism of arachidonic acid. Extracts of $S$. reticulata var. mandshurica have been used for treating bronchitis, and one of its constituents 2-(3, 4-dihydroxyphenyl) ethanol (91) significantly inhibited the production of phlegm [2].

\section{Review and conclusions}

This review describes phytochemical and pharmacological progress on the genus Syringa in the recent 20 years and discusses the future research prospects.

Syringa plants are used not only as traditional medicines to treat rheumatoid arthritis, asthma, cardiopalmus, and angina pectoris by natives in China but also for making ornaments, volatile oils, food additives, and bactericides worldwide, particularly in developing countries. Previous phytochemical studies on crude extracts from various species of this genus have identified iridoids, lignans, phenylpropanoids, and phenylethanoids having antitumor, antihypertensive, anti-oxidant, and anti-inflammatory activities. Iridoids, lignans, and phenylethanoids are the most predominant compounds in Syringa plants that probably contribute independently or synergistically to their main biological activities.

To the best of our knowledge, 46 iridoid representatives have been reported in Syringa plants, with high concentrations present in the leaves of S. vulgaris, $S$. pubescens, S. afghanica, S. reticulata, and S. velutina and barks of $S$. vulgaris and S. reticulata and low concentrations present in the flowers (S. pubescens), seeds, and seeds crust (S. oblata). This difference may be associated with their ecological roles, because iridoids are produced mainly to fight predators and/or microbes. Moreover, high concentrations of lignans in the stems and roots can be attributed to the rigidity of these plants. This may be the reason for the absence of iridoids in S. pinnatifolia var. alashanensis because materials used for chemical investigation included peeled stems and roots. Anti-inflammatory effects of extracts from these plants are mainly responsible for their applications in traditional medicine. However, only preliminary work has been performed on most isolated compounds, such as in vitro cytotoxicity screening $(\mathbf{1}, \mathbf{2}, \mathbf{7 8}$, and $\mathbf{1 3 9})$. Limited studies have been performed on the in vivo effects of these compounds; thus, providing opportunities for further detailed research. It is particularly worthy to mention that China has an abundant resource of Syringa, with many endemic species. For instance, S. pinnatifolia var. alashanensis is a well-known Mongolian medicine traditionally used for myocardial ischemia in clinical practice. However, no substantial evidence is available on its bioactive ingredients and mechanisms of action underlying this effect. Therefore, it deserves further phytochemical and pharmacological studies. 


\section{Competing interests}

The authors declare that they have no competing interests.

\section{Authors' contributions}

SG, CY, LC, GX, and YX have all been involved in preparing this review. SG, TP and $C X$ are responsible for writing, checking and revising the manuscript. All authors read, discussed and approved final version of the manuscript.

\section{Acknowledgments}

This paper is financially supported by the National Natural Science Foundation of China (No.81473426).

\section{Author details}

${ }^{1}$ Modern Research Center for Traditional Chinese Medicine, Beijing University of Chinese Medicine, 11 North 3rd Ring Road, Chaoyang District, Beijing 100029, P. R. China. ${ }^{2}$ School of Chinese Materia Medica, Beijing University of Chinese Medicine, 6 Wangjing Southern Middle Ring Road, Chaoyang District, Beijing 100102, P. R. China.

\section{Received: 26 April 2014 Accepted: 7 January 2015}

Published online: 27 January 2015

\section{References}

1. Editorial Committee of Chinese Material Medica. Chinese Material MedicaMongolian volume. Shanghai Sci Technol Press. 1992;61:2-50.

2. Zhang JF, Zhang SJ. An overview of the genus Syringa: phytochemical and pharmacological aspects. Nat Sci J Hainan Univ. 2007;2:201-5.

3. Deng RX, Yuan H, Liu P, Yin WP, Wang XS, Zhao TZ. Chemical constituents from Syringa pubescens Turcz. Biochem Syst Ecol. 2010;38:813-5.

4. Zhang GB, Liu LJ, Wang MK. Chemical constituents of volatile oils from Syringa pinnatifolia. Chin Pharm J. 1994;5:271.

5. SamyK ED, GamalEldeen AM. Cytotoxic and anti-inflammatory activities of some constituents from the floral buds of Syringa patula. Pharm Biol. 2009;47:872-7.

6. Dinda B, Debnath S, Harigaya Y. Naturally occurring iridoids. a review, part 1. Chem Pharm Bull. 2007:55:159-222.

7. Ghisalberti EL. Biological and pharmacological activity of naturally occurring iridoids and secoiridoids. Phytomedicine. 1998;5:147-63.

8. Oh H, Ko EK, Kim DH, Jang KK, Park SE, Lee HS, et al. Secoiridoid glucosides with free radical scavenging activity from the leaves of Syringa dilatata. Phytother Res. 2003;17:417-9.

9. Masafumi K, Yasunri Y, Nariyasu M. Glycoside from the leaves of Syringa vulgaris and their growth inhibitory activity against human cancer cell lines. Japan Soc Pharm. 2010;64:104-5.

10. Bi XY, Li W, Sasaki T, Li Q, Mitsuhata N, Asada Y, et al. Secoiridoid glucosides and related compounds from Syringa reticulata and their anti-oxidant activities. Bioorg Med Chem Lett. 2011;21:6426-9.

11. Kikuchi M, Yaoita Y, Mano N, Kikuchi M. Structure and cytotoxic activity of enzymatic hydrolysis products of secoiridoid glucosides, isoligustroside and isooleuropein. Chem Biodivers. 2011;8:651-7.

12. Park HJ, Lee MS, Lee KT, Sohn IC, Han YN, Miyamoto K. Studies on constituents with cytotoxic activity from the stem bark of Syringa velutina. Chem Pharm Bull. 1999;47:1029-31.

13. Yk T, Okazaki N, Tanahashi T, Nagakura N, Nishi T. Secoiridoid and iridoid glucosides from Syringa afghanica. Phytochemistry. 2002;59:779-87.

14. Nenadis N, Vervoort J, Boeren S, Tsimidou MZ. Syringa oblata Lindl var. alba as a source of oleuropein and related compounds. J Sci Food Agr. 2007;87:160-6.

15. Kikuch IM, Yamauchi Y, Yanase C. Structures of new secoiridoid glycosides from the leaves of Syringa vulgaris Linn. Yakugakuzasshi. 1987;107:245-8.

16. Machida K, Kaneko A, Hosogai T, Kakuda R, Yaoita Y, Kikuchi M. Studies on the constituents of Syringa species. $X$. five new iridoid glycosides from the leaves of Syringa reticulata (Blume) Hara. Chem Pharm Bull. 2002;50:493-7.

17. Sticher O, Ahmad M, Salama O, Winkler T. Two new secoiridoid glucosides from Syringa vulgaris. Planta Med. 1982;45:151

18. Kikuch IM, Yamauchi Y, Takahashi Y. Structures of new secoiridoid glycosides from the leaves of Syringa vulgaris Linn. Yakugakuzasshi. 1988;108:355-60

19. Machida K, Unagami E, Ojima H, Kikuchi M. Studies on the constituents of Syringa species. XII. new glycosides from the leaves of Syringa reticulata (Blume) Hara. Chem Pharm Bull. 2003;51:883-4.
20. Garcia J, Lavaitte S, Gey C. 8-Epikingiside and its vanillate ester, isolated from Gentiana pyrenaica. Phytochemistry. 1989;28:2199-201.

21. Feng XS, Qu Y, Wu ZHXL, Zhang DS, Gao HY, Wu L. Two new secoiridoid glucosides from Syringa velutina Kom. Chinese Chem Lett. 2009;20:702-5.

22. Asaka Y, Kamikawa T, Tokoroyama T, Kubota T. The structure and absolute configuration of syringopicroside. a new iridoid glucoside from Syringa vulgaris. Tetrahedron. 1970;26:2365-70.

23. Zhou YM, Gao HY, Wu B, Li SH, Wu LJ. Structure determination of syringopicroside from the leaves of Syringa oblata Lindl. using 2D NMR spectral methods. Asian J Tradit Med. 2006;1:31-3.

24. Zhang SJ, Guo HQ, Han J, Zhao M, Wang JJ. Chemical constituents from seeds of Syringa oblata. Chin Tradit Herbal Drugs. 2011;42:1894-900.

25. Wang JL, Zhang GF, Dong LW, Zhao M, Zhang SJ. Chemical constituents from seed crust of Syringa oblata. Chin Tradit Herbal Drugs. 2010;41:1598-601.

26. Kikuch IM, Yamauchi Y, Takahashi Y. Studies on constituents of Syringa species. VIII. Isolation and structures of phenylpropanoid glycosides from the leaves of Syringa reticulata (Blume) Hara. Yakugakuzasshi. 1989;109:366-71.

27. Luo Y, Liu Y, Qi H, Wu Z, Zhang G. Steryl esters and phenylethanol esters from Syringa komarowii. Steroids. 2006;71:700-5.

28. Feng XS, Qu Y, Xu L, Wang DC, Wu LJ, Meng FH, et al. Two new neolignans from Syringa velutina Kom. Molecules. 2009;14:953-8.

29. Kurkin VA. Phenylpropanoids from medicinal plants: distribution, classification, structural analysis, and biological activity. Chem Nat Compd. 2003;39:123-53.

30. Zeng XJ, Wang GC, Wu X, Li YL. Chemical constituents from Syringa pinnatifolia. Chin Tradit Herbal Drugs. 2013;7:1721-5.

31. Ao WL, Bao XH, Wu XL, Wang QH. Lignans from Syringa pinnatifolia var. alashanensis. J Asian Nat Prod Res. 2012;14:396-400.

32. Xu QM, Li Q, Liu YL, Feng YL, Yang SL, Li XR. New lignans from Syringa reticulata var. mandshurica. Chem Nat Compd. 2010;46:366-9.

33. Wang $\mathrm{QH}, \mathrm{Ao} \mathrm{WL}$, Wu QS, Ying X. Two new neolignans from the stems of Syringa pinnatifolia var. alashanensis. Helv Chim Acta. 2012;95:1680-5.

34. Ao WL, Wang QH, Wang XL, Dai YNT. Extraction and structure elucidation of three lignans from peeled dried roots and stems of Syringa pinnatifolia. Chin Tradit Herbal Drugs. 2013;7:791-3.

35. Machida K, Ohkawa N, Ohsawa A, Kikuchi M. Two new phenolic glycosides from Syringa reticulata. J Nat Med. 2009;63:192-4.

36. Ahmad M, Rizwan GH, Aftab K, Ahmad VU, Gilani AH, Ahmad SP. Acteoside: a new antihypertensive drug. Phytother Res. 1995;9:525-7.

37. Ao WL, Wang QH, Si Q, Mu D, Sa RTY, Dai NYT, et al. The structural elucidation and antimicrobial activities of two new sesquiterpenes from Syringa pinnatifolia. Chin J Nat Med. 2012;10:477-80.

38. Li ZG, Lee MR, Shen DL. Analysis of volatile compounds emitted from fresh Syringa oblata flowers in different florescence by headspace solid-phase microextraction-gas chromatography-mass spectrometry. Anal Chim Acta. 2006;1:43-9.

39. Chen $X Z$, Liang $Y Z$, Fang HZ, Li XN. Temperature-programmed retention indices for gas chromatography-mass spectroscopy analysis of plant essential oils. J Chromatogr A. 2005;1096:76-85.

40. Yu AN, Yang XZ. Chemical composition of the essential oil of fresh wild Syringa pubescens flowers from China. Adv MaterRes (Durnten-Zurich, Switzerland). 2012;22:581-2.

41. Kikuch IM, Yamauchi Y. Studies the constituents of Syringa species. I. Isolation and structures of iridiods and secoiridoids from the leaves of Syringa reticulata (Blume) Hara. Yakugakuzasshi. 1987;107:350-4.

42. Ahmad M, Salama O, Sticher O. Isolation of echinacoside from the white flowers of Syringa vulgaris. J Chem Soc Pakistan. 1987;9:451-4.

43. Xu QM, Liu YL, Li XR, Feng YL, Yang SL. Two new phenylglycol derivatives isolated from Syringa reticulata var. mandshurica and their antifungal activities. Chem Pharm Bull. 2009;57:863-6.

44. Ao WL, Wang QH, Dai YNT. Chemical detection on the stems of Syringa pinnatifolia var. alashanensis. Chin Hosp Pharm J. 2013;33:1544-6.

45. Kurkin VA. Phenylpropanoids as the biologically active compounds of the medicinal plants and phytopharmaceuticals. Adv Biol Chem. 2013;3:26-8.

46. Ahmad M, Aftab K. Hypotensive action of syringin from Syringa vulgaris. Phytother Res. 1995;9:452-4.

47. Kikuch IM, Yamauchi Y. Studies on constituents of Syringa species I. Isolation and structure of iridodids and secoiridoids from the leaves of Syringa reticulata (Blume) Hara. Yakugakuzasshi. 1987;107:23-7.

48. Kurkin VA, Zapesochnaya GG, Ginenko NA, Zolotarev BM. Phenolic compounds from the bark of Syringa vulgaris. Chem Nat Compd. 1989;4:581-3. 
49. Ahmad M, Salama O. Flavonoids from violet flowers of Syringa vulgaris. Pakistan J Sci Ind Res. 1987;30:150-1.

50. Ahmad M, Salama O. Isolation of rutin from the fresh leaves of Syringa vulgaris. J Pharm. 1985;4:9-11.

51. Yin WP, Zhao TZ, Zhang HY. A novel oligosaccharide ester from Syringa pubescens. J Asian Nat Prod Res. 2008;10:95-100.

52. Helmut R. Jasminidin, ein neues monoterpenalklaloid aus Syringa vulgaris. Phytochemistry. 1978;17:1069-70.

53. Liu X, Wang JM. Iridoid glycosides fraction of Folium Syringae leaves modulate NF-KB signal pathyway and intestinal epithelial cells apoptosis in experimental colitis. Plos One. 2011;6:e24740.

54. Liu X, Wang JM. Anti-inflammatory effects of iridoid glycosides fraction of Folium Syringae leaves on TNBS-induced colitis in rats. J Ethnopharmacol. 2011;133:780-7.

55. Gao SQ, Niu JQ, Wang F, Wang F, Liu XD, Jin ZX, et al. Comparative studies on the resistance of hepatitis B by Syringa extract, IFN and ganyanling in HepG2.2.15 cells. Chin J Cell Mol Immunol. 2003:19:385-6.

56. Yao DL, Han ZG, Zhou W, Ju GM, Li G. Protective effects of the Syringa reticulata var. mandshurica extract against acute liver injury in mice. J Med Sci Yan B Univ. 2009;32:29-31.

57. Li JX. The Syringa aramaticum modern pharmacological research. P J Pract Tradit Chin Med. 2002;18:54.

58. Yan Y, WU O, Zhao XJ, Ye XC, Zhang C, Hao JJ, et al. Effect of essential oil of Syringa pinnatifolia var. alashanensis on ischemia of myocardium, hypoxia and platelet aggregation. J Ethnopharmacol. 2010;131:248-55.

59. Balint G, Eperjessy ET, Thuranszky K. Hypothermic action of the leaf extract of Syringa vulgaris. Acta Physiolo Acad Sci Hung. 1965;28:399-406.

60. Yang WW, Xing MY. The preparations of Syringa oblata leaves change in immunoassay after the treatment on herpes simplex keratitis. Chin J Pract Ophthalmolol. 1990;8:252-61.

61. Xing MY. The preparations of Syringa oblata leaves change in tears' $\mathrm{PH}$ after the treatment on herps simplex keratitis. Chin J Ophthalmolol. 1992;10:312-21.

62. Xing MY, Li B. The preparations of Syringa oblata leaves treat epidemic hermorrhagic conjunctivitis. Chin J Ophthalmolol. 1996;14:301.

63. Li SJ, Xu LY. The preparations of Syringa oblata leaves treat hemorrhoids with 18 cases. China Acad J. 2001;1:57.

\section{Publish with ChemistryCentral and every scientist can read your work free of charge \\ "Open access provides opportunities to our colleagues in other parts of the globe, by allowing anyone to view the content free of charge." \\ W. Jeffery Hurst, The Hershey Company. \\ - available free of charge to the entire scientific community \\ - peer reviewed and published immediately upon acceptance \\ - cited in PubMed and archived on PubMed Central \\ - yours - you keep the copyright \\ Submit your manuscript here: \\ http://www.chemistrycentral.com/manuscript/<smiles>c1ccccc1</smiles> \\ Chemistry Central}

